American Journal of Applied Sciences 7 (1): 13-16, 2010

ISSN 1546-9239

(C) 2010 Science Publications

\title{
Antibacterial Activity of Hydroalcoholic Extract of Callistemon citrinus and Albizia lebbeck
}

\author{
Seyyed Mansour Seyydnejad, Masumeh Niknejad, Ismaieel Darabpoor and Hossein Motamedi \\ Department of Biology, School of Science, Shahid Chamran University, \\ Postal Code: 65355-141, Ahwaz, Iran
}

\begin{abstract}
Problem statement: Callistemon citrinus and Albizia lebbeck are two kind of native plants in Khoozestan province in Iran, according to the agreement that medicinal plant could be replaced the medicine we are trying to determine the antibacterial effect of the named plants. Approach: The antibacterial properties of ethanolic and methanolic extract of Callistemon citrinus leaf and Albizia lebbeck leaf was studied against different pathogenic bacteria including Streptococcus pyogenes, Bacillus cereus, Bacillus anthracis, Salmonella typhi, Kelebsiella pneumoniae, Streptococcus epidermidis, Escherichia coli, Pseudomonas aeruginosa and Listeria monocytogenes by disc diffusion method. The samples collected from young trees from Ahvaz city at may 2009. Results: The extract of $C$. citrinus showed significant activity against the majority of bacteria which is comparable with standard antibiotics. Minimum Inhibitory Concentration (MIC) and Minimum Bactericidal Concentration (MBC) for hydroalcoholic extract of Callistemon have been determined also for four bacteria; S. pyogenesis, S. typhy, B. anthrasis, S. typhy, Albizia lebbeck extract despite previous reports didn't have any significant effect. Conclusion: According to the good effects of Callistemon citrinus on Bacillus species it has antiseptic effects and could be used as a therapeutic agent and therefore, it appears to be a potent antimicrobial agents that could be considered as a medicinal plant.
\end{abstract}

Key words: Callistemon citrinus, Albizia lebbeck, antibacterial, MIC, MBC

\section{INTRODUCTION}

The use of herbs and medicinal plant as the first medicines is a universal phenomenon. Every culture on the earth, through written or oral tradition, has relied on the vast variety of natural chemistrie's found in plants for their therapeutic properties. All drugs from the plant are substances with a particular therapeutic action extracted from plants (Serrentino, 1991). The usage of herbal plants as traditional health remedies is the most popular for $80 \%$ of the world population in Asia, Latin America and Africa and is reported to have minimal side effect (Doughari, 2006).

In this study 2 plant species have been selected; Callistemon citrinus and Albizia lebbeck.

Callistemon citrinus (Family: Myrtaceae) the common name, "bottlebrush", perfectly describes this evergreen plant's bright red flower spikes. The flowers are followed by small; woody capsules that look like bead bracelets on the bark, and which last for years.

Albizia lebbeck (native name: Borhan; Family: Leguminosae) is a deciduous tree with compound leaves, flat oblong fruits, round cream colored seeds, grows wild and planted in almost all districts of Bangladesh (Ghani, 2003). This plant is found throughout India, Bangladesh, tropical and subtropical Asia and Africa (Kirtikar and Basu, 1980).

Many studies have been done on medical properties of different species of C. citrinus: Antibacterial, antifungal and antioxidant activities of methanolic extract obtained from Callistemon linearis DC. Leaf have been studied. Methanolic extract exhibited potential antimicrobial activity against both gram positive as well as gram negative bacteria and moderate activity against fungal species . This extract also shows good antioxidant activity (comparable with standard Ascorbic acid)which is concentration dependent (Anudwipa Das et al., 2008).

There are also lots of data on therapeutic properties of Albizia lebbeck: The Ethanolic extract of pods possesses antiprotozoal, hypoglycemic and anticancer properties. The methanolic extract of the pod was investigated for antifertility effect (Gupta et al., 2004; 2005). Although A. lebbeck has traditionally been used in the treatment of many types of pain and inflammatory conditions. The analgesic and anti-

Corresponding Author: Seyyed Mansoor Seyydnejad, Department of Biology, School of Science, Shahid Chamran University, Postal Code: 65355-141, Ahwaz, Iran 
inflammatory effect of A. lebbeck have been reported (Achinto and Munirrudin, 2009). The in vitro antibacterial activates of $80 \%$ methanolic crude extracts prepared from the seeds of Ablizia gummifera was tested for inhibitory activity against the clinical isolates of six S. pneumonae and twenty two S. pyogenes using agar dilution method (Abayneh, Unasho, 2005).

This study is an attempt to determine antimicrobial activity of Calistemon citrinus and Albizia lebbeck leaf ethanolic and methanolic extract on selected pathogenic bacteria isolated from patients.

\section{MATERIALS AND METHODS}

Collection of plant material: The C. citrinus (Bottle brush tree) and A. lebbeck were collected from Ahvaz in Khuzestan province of Iran at May, 2009. The taxonomic identification of these plants was confirmed by department of biology, Chamran University, Iran.

Extract preparation: The leaves of each considered plant were shade dried for $48 \mathrm{~h}$ and crushed into powder using blender, $6 \mathrm{~g}$ of powder were used for extraction. $10 \mathrm{~mL}$ of ethanol distilled water $(8: 2 \mathrm{w} / \mathrm{v}) \mathrm{g}^{-1}$ were used to make ethanolic extract and $10 \mathrm{~mL}$ methanol distilled water $(8: 2 \mathrm{w} / \mathrm{v}) \mathrm{g}^{-1}$ for methanolic extract, then centrifuged (3000 rpm) for $15 \mathrm{~min}$ and the supernatants were harvested. The process repeated three times. Finally the alcohol was removed by evaporation through incubating at room temperature. (Seyyednejad et al., 2001; Moazedi et al., 2007) the methanolic extract prepared following the method described above by Okemo et al. (2001).

Test microorganisms: A total of eight bacterial species were tested including Streptococcus pyogenes, Bacillus cereus, Bacillus anthracis, Salmonella typhi, Kelebsiella pneumoniae, Streptococcus epidermidis, Escherichia coli, Pseudomonas aeruginosa, Listeria monocytogenes that were isolated from medicinal samples. They were identified using standard biochemical tests.

Antimicrobial assay: The antimicrobial activity of the ethanolic and methanolic extract was determined based on inhibition zones in disc deffusion method described by (Bauer et al., 1996). Mueller-Hinton agar was the media which is selected for preparing test plates. In all cases, the inoculums were contained in the nutrient agar plates for bacteria and previously prepared ethanolic extract and methanolic extract impregnated disc (5 $\mathrm{mm}$ in diameter bloating paper disc) at concentration of $100 \mu \mathrm{g} \mathrm{mL} L^{-1}$ for bacteria and were placed aseptically on sensitivity plates with appropriate control were used as standard antibacterial respectively. The plates were incubated for $24 \mathrm{~h}$ at $37^{\circ} \mathrm{C}$ for bacteria (Bauer et al., 1996). Control discs were soaked with the same extraction solvents and treated as the sample discs. The positive results (sensitivity) were established by the presence of clear zone of inhibition around active extracts which were measured with a meter rule and diameters were recorded based on $\mathrm{mm}$.

Determination of Minimum Inhibitory Concentration (MIC): The Minimum Inhibitory Concentration (MIC) of the extracts was determined for the most sensitive bacterial species for three times. A $16 \mathrm{~h}$ culture was diluted with a sterile Physiologic Saline solution (PS; $0.85 \%(\mathrm{w} / \mathrm{v})$ sodium chloride) with reference to the 0.5 McFarland turbidometry to achievement of inoculums approximately $10^{8}$ colony forming units (cfu) $\mathrm{mL}^{-1}$ (Burt and Reinders, 2003) a serial dilution was carried out to give final concentrations between 0.5-0.0025 from crud extract. The tubes were inoculated with 30 micro liter of the bacterial suspension $\mathrm{mL}^{-1}$ of Muller Hinton broth, homogenized and incubated at $37^{\circ} \mathrm{C}$. The Minimum Inhibitory Concentration (MIC) value was determined as the lowest concentration of the crude extract in broth medium that inhibited the visible growth of the test microorganism (Motamedi, 2009).

Determination of Minimum Bactericidal Concentration (MBC): To determine the MBC, for each set of test tubes in the MIC determination, a loop full of broth was collected from those tubes which did not show any growth and inoculated on sterile MullerHinton agar by streaking. The plates were inoculated at $37^{\circ} \mathrm{C}$ for $18-24 \mathrm{~h}$. The highest dilution that yielded no colony fraction on a solid medium was considered as MBC (Motamedi, 2009).

\section{RESULTS}

The antimicrobial activity of Ethanolic and Methanolic extract of Callistemon citrinus was resulted to a growth inhibition pattern against the tested microorganism. The results of the antimicrobial activity were given in the Table 1. These data revealed that the ethanolic and methanolic extract showed good antimicrobial activity against bacteria. It is noteworthy in particular effect against Salmonella, B. cereus, S. epidermis, B. anthracis which is comparable with antibiotics. The results of MIC and MBC of 4 bacteria species are shown in Table 2.

In this case the methanol and ethanol extract of Albizia lebbeck were also examined and didn't have any antibacterial effect. 
Am. J. Applied Sci., 7 (1): 13-16, 2010

Table 1: Results of antibacterial activity of ethanolic and methanolic extract of Callistemon citrinus leaf

\begin{tabular}{|c|c|c|c|c|c|c|c|c|c|c|c|c|}
\hline \multirow[b]{2}{*}{ Bacteria species } & \multicolumn{4}{|c|}{ Ethanol } & \multicolumn{4}{|c|}{ Methanol } & \multicolumn{4}{|c|}{ Antibiotic disc* } \\
\hline & 0.4 & 0.2 & 0.1 & 0.05 & 0.4 & 0.2 & 0.1 & 0.05 & $\mathrm{NF}$ & $\mathrm{CB}$ & NB & $\mathrm{DX}$ \\
\hline \multicolumn{13}{|l|}{ Gram positive } \\
\hline S. aureus & 10 & 10 & 9 & $\mathrm{R}$ & - & - & - & - & $\mathrm{R}$ & 13 & 31 & 15 \\
\hline B. anthracis & 13 & 11 & 10 & $\mathrm{R}$ & 22 & 19 & 19 & 20 & $\mathrm{R}$ & 28 & 20 & 32 \\
\hline B. cereus & 17 & 17 & 15 & 14 & 17 & 16 & 16 & 15 & $\mathrm{R}$ & 7 & 18 & 18 \\
\hline S. pyogenes & 24 & 23 & 22 & 25 & 25 & 25 & 41 & 30 & $\mathrm{R}$ & 36 & 39 & 21 \\
\hline L.monocytogenes & - & - & - & - & 16 & 16 & 15 & 14 & 25 & 19 & 12 & 20 \\
\hline \multicolumn{13}{|l|}{ Gram negative } \\
\hline S. typhi & 22 & 21 & 17 & 15 & 15 & 12 & 12 & 11 & $\mathrm{R}$ & 27 & 34 & 30 \\
\hline Kelebsiella pneumoniae & $\mathrm{R}$ & $\mathrm{R}$ & $\mathrm{R}$ & $\mathrm{R}$ & 11 & 9 & 11 & 9 & $\mathrm{R}$ & $\mathrm{R}$ & 11 & $\mathrm{R}$ \\
\hline E coli & $\mathrm{R}$ & $\mathrm{R}$ & $\mathrm{R}$ & $\mathrm{R}$ & $\mathrm{R}$ & $\mathrm{R}$ & $\mathrm{R}$ & $\mathrm{R}$ & $\mathrm{R}$ & $\mathrm{R}$ & 17 & 11 \\
\hline P. aeruginosa & - & - & - & - & 16 & 18 & 15 & 14 & $\mathrm{R}$ & $\mathrm{R}$ & 16 & $\mathrm{R}$ \\
\hline
\end{tabular}

*: (6 mm) diameter disc; R: Resistant; -: Not used

Table 2: Antibacterial activity (MIC and $\mathrm{MBC}$ in $\mathrm{mg} \mathrm{mL}^{-1}$ ) of the ethanolic and methanolic extract of Callistemon citrinus on come tested bacteria

\begin{tabular}{|c|c|c|c|c|}
\hline \multirow{3}{*}{$\begin{array}{l}\text { Bacteria } \\
\text { species }\end{array}$} & \multicolumn{4}{|l|}{ Extract } \\
\hline & \multicolumn{2}{|l|}{ Ethanolic } & \multicolumn{2}{|l|}{ Methanolic } \\
\hline & S. pyogenesis & S. typhy & B. anthrasis & S. typhy \\
\hline MIC & 5.0 & 40 & 10 & 20 \\
\hline $\mathrm{MBC}$ & 2.5 & 80 & 20 & 40 \\
\hline
\end{tabular}

\section{DISCUSSION}

The antimicrobial activities of various plants have been reported by many Researchers (Cowan, 1999; Dewanjee, 2008). As the plant produce secondary metabolites in order to protect themselves from microorganism, herbivores and insects, thus antimicrobial effect is somehow expected from plants namely flavonoids, alkaloids and triterpenoid are producing a better opportunity for testing wide range of microorganism.

In the present study a variety of gram positive and gram negative strains were selected for screening antimicrobial effects of ethanolic and methanolic extract of Callistemon citrinus and Albizia lebbeck leaf. The result of this study showed that the ethanolic and methanolic extract of Callistemon citrinus exhibited varied range of antimicrobial activity against the tested organism including gram positive and gram negative bacteria, which is comparable to standard antibiotic effect.

The Callistemon extracts exhibited the greatest antimicrobial activities (as determined by the diameters of the inhibition zones towards the most susceptible bacteria like Bacillus species, S. pyogenesis, S. Typhi and $P$. aeruginosa.

Escherichia coli was resistant to methanolic and ethanolic extract that probably could be due to cell membrane permeability or due to other genetic factors this result is supported by Nazif et al. (2002) and Motamedi et al. (2009).

Impact of methanolic and ethanolic extract of C. citrinus on S. pyogenes in lower dilution of extract increased. It could be related to reduce dilution of some inhibitory factors in the extract. Good effect of extract of this plant on P. aeruginosa that is a resistant bacteria is also noticeable. finally impact of the extract on gram positive bacteria are more notify than gram negatives, it is because of structure of membrane that the $\mathrm{G}^{+}$bacteria are more simple than $\mathrm{G}^{-}$ones. In some cases methanolic extract showed stronger effect than ethanolic extract, it could be because of the difference between extract compounds in this two extract.

Despite previous records, A. lebbeck extract didn't show any inhibitory effect. It could because of ecological reasons. According to pharmacognosy science it is clear today that if the plant cultivated in different lands different types and concentrations of materials it will have. The other points that could be considered as the reason are plant growing location, height, climate, humidity and dryness, temperature, amount of sun levels, sex, soil, rainfall, time of collection, how to keep dry, age of plant and kind of organs used as therapeutic. Another problem due to medicinal effects of plants is geographical origin. The native place that the best and the most effective plants are grown up named geographical origin. A plant that is grows in different places in or out of geographical origin doesn't have the same substances and effects; it is because the weather condition is very decisive in producing officinal substances (Salehi Sormaghi, 2008).

\section{CONCLUSION}

Based on the result of this study it can be said that C. citrinus is an effective antimicrobial plant that can be used for folk medicine and will be a good source for 
finding new antimicrobial agents in order to treat and control infections.

\section{REFERENCES}

Abayneh Unasho, 2005. Investigation of antimicrobial activities of Albizia gummifera and Ferula communis on Streptococcus pnemoniae and streptococcus pyogenes causing upper respiratory tract infections in children. Thesis Biology, Faculty of Science, Addis Ababa University. http://hdl.handle.net/123456789/922

Anudwipa Das, K. Jaman, Akhilesh and V. Singh, 2008. Antimicrobial and antioxidant activities of Callistemon linearis DC leaf extract. Pharmacologyonline, $\quad 3$ : $\quad 875-881$ http://www.unisa.it/download/1966_10305_12750 16968_90_Das.pdf

Achinto Saha and Munirudin Ahmed, 2009. The Analgestic and anti-inflammatory activities of the extract of Albizia lebbeck in animal model. Pak. J. Pharm. Sci., 22: 74-77. http://www.pjps.pk/CDPJPS-22-1-09/Paper-14.pdf

Bauer, A.W., W.M. Kirby, J.C. Sherris and M. Turck, 1996. Antibiotic susceptibility testing by a standardized single disk method. Am. J. Clin. Pathol., 45: 493-496. http://content.karger.com/ProdukteDB/produkte.as p?Aktion $=$ ShowFulltext\&ProduktNr=223834\&Aus gabe $=224896 \&$ ArtikelNr $=7119$

Cowan, M.M., 1999. Plant products as antimicrobial agents. Clin. Microbial. Rev., 22: 564-582. http://www.bio.uaic.ro/publicatii/anale_biochimie/ 2007_VIII_f1/2007_Anale_GBM_VIII_f1_126.pdf

Dewanjee, S., A. Maiti, R. Majumder and A. Majumder, 2008. Evaluation of antimicrobial activity of hydroalcohalic extract of Schma wallichii bark. Pharmcolologyonline, $\quad 1$ : 523-528. http://informahealthcare.com/doi/abs/10.1080/1388 0200902758824? cookieSet $=1$ \&journalCode $=$ phb
Doughari, J.H., 2006. Antimicrobial activity of Tamarindus indica Linn. Trop. J. Pharm. Res., 5: 597-603. http://ajol.info/index.php/tjpr/article/viewFile/14637 12742

Kirtikar, K.R. and B.D. Basu, 1980. Indian Medicinal Plants. 2nd Edn., Bishen Singh, Mahendra Pal Singh, India, pp: 33.

Moazedi, A.A., N. Mirzaie Damabi, S.M. Seyyednejad, M.R. Zadkarami and A. Amirzargar, 2007. Spasmolic effect of Petrosselinum crospum (parsly) on rats ileum on different calcium chloride concentrations. Pak. J. Biol. Sci., 10: 4036-4042. http://scialert.net/pdfs/pjbs/2007/4036-4042.pdf

Motamedi, H., A. Safary, S. Maleki and S.M. Seyyednejad, 2009. Ziziphus spina-christi, a native plant from Khuzestan, Iran, as a potential source for discovery new antimicrobial agents. Asian J. Plant Sci., 8: 187-190. http://scialert.net/qredirect.php?doi=ajps.2009.187. 190\&linkid $=$ pdf

Nazif, N.M., 2002. Phytoconstituents of Ziziphus spina-christi L. fruits and their antimicrobial activity. Food Chem., 76: 77-81. http://cat.inist.fr/?aModele $=$ afficheN\&cpsidt $=1342$ 4536

Okemo, P.O., W.E. Mwatha, S.C. Chhabra and W. Fabry, 2001. The kill kinetics of Azadirachta indica a. juss. (meliaceae) extract on Staphylococcus aureus, E. coli, Pseudomonas aeroginosa and Candida albicans. Afr. J. Sci. Tech., 2: 113-118. http://www.ansti.org/2001/113-118.pdf

Salehi Sormaghi, M.H., 2008. Medicinal Plants and Phytotherapy. World of Nutrition Publisher, Tehran Iran, ISBN: 964-96959-2-3, pp: 47-48.

Serrentino J., 1991,How Natural Remedies Work. Harley and Marks Publishers, Point Robert, WA., pp: 239. http://indjst.org/archive/issue6/nov08ganges.pdf 